\title{
SIMULASI MONTE CARLO DENGAN MODEL PERSEDIAAN STOKASTIK PADA PT.BINGEI MEDAN
}

\author{
${ }^{1}$ Roni Jhonson Simamora, ${ }^{2}$ Jamaluddin \\ ${ }^{1,2}$ Program Studi D-III Manajemen Informatika, Universitas Methodist Indonesia \\ ${ }^{1}$ ronimor4@gmail \\ 2james_coleps@yahoo.com
}

\begin{abstract}
Inventory systems or inventory is very important for a company, especially if the company is engaged in the distribution of goods. PT. Bingei Medan is a company engaged in the sale of fertilizers. The availability of fertilizers in fulfilling customer orders to be very important, it is necessary to well-managed inventory. The purpose of this study is to make simulation using the programming language Microsoft Visual Basic Version 6.0 and simulations built a simulation model of the stochastic inventory system PT. Bingei Medan. And the results of this simulation to analyze the characteristics of inventory system such as the average level of availability of goods, the amount of goods ordered, the number of items that are not fulfilled (stock out) and the amount of time ordering goods.
\end{abstract}

Keywords :_Simulation, Inventory Systems, Stochastic Model

\section{PENDAHULUAN}

Masalah persediaan tidak hanya ada di perusahaan manufaktur saja, tetapi masalah tersebut juga terjadi pada perusahaan yang bergerak dalam bidang penjualan. Permasalahan persediaan juga terjadi pada PT. Bingei Medan merupakan perusahaan yang bergerak dibidang penjualan pupuk. Sistem persediaan pupuk yang digunakan pada perusahaan ini kebanyakan masih menggunakan perkiraan, intuisi, dan kebiasaan. Kesalahan dalam penaksiran persediaan menjadi sangat berisiko ketika menggunakan model persediaan yang masih sederhana tersebut. Tanpa adanya pengelolaan persediaan yang baik maka perusahaan akan dihadapkan pada resiko suatu waktu tidak dapat memenuhi kebutuhan permintaan pelanggan sehingga perlu dilakukan analisis persediaan.

Analisis sistem persediaan yang berjalan pada PT Bingei Medan memiliki sifat permintaan dan lead time yang tidak dapat diprediksi/tidak pasti. Dari analisis tersebut, dapat diketahui model persediaan yang digunakan. Dengam model persediaan maka didapat gambaran mengenai sistem persediaan yang dikelola.

Model persediaan stokastik merupakan model persediaan di mana pemintaan barang dan lead time memiliki sifat yang tidak dapat diprediksi/tidak pasti (Nur, Senator. B, 2006).

Masalah persediaan paling sesuai diselesaikan dengan pendekatan simulasi, yang berfungsi untuk meniru perilaku sistem nyata. Simulasi merupakan salah satu alat yang sering digunakan oleh manajemen dalam mempelajari atau menganalisis perilaku kerja dari suatu sistem atau proses (Sridadi, B, 2009).

Oleh karena itu diperlukan simulasi inventori dengan model stokastik pada PT. Bingei Medan yang dapat diaplikasikan dalam menganalisis karakteristik sistem persediaan tersebut.

Tujuan penelitian ini adalah membuat program simulasi dengan menggunakan bahasa pemograman Microsoft Visual Basic Versi 6.0 dan simulasi yang dibangun adalah simulasi inventori untuk model persediaan stokastik Pada PT. Bingei Medan. Manfaat Penelitian ini dapat mengetahui karakteristik sistem persediaan seperti bagaimana tingkat ketersediaan 
(stock) awal dan akhir, bagaimana rata-rata stock awal, stock akhir dan stock out, serta bagaimana jumlah pesan, jumlah stock out dan jumlah waktu pemesanan.

\section{METODE PENELITIAN}

Metode Penelitian ini menggunakan pendekatan Simulasi dengan langkah-langkah sebagai berikut (gambar 2):

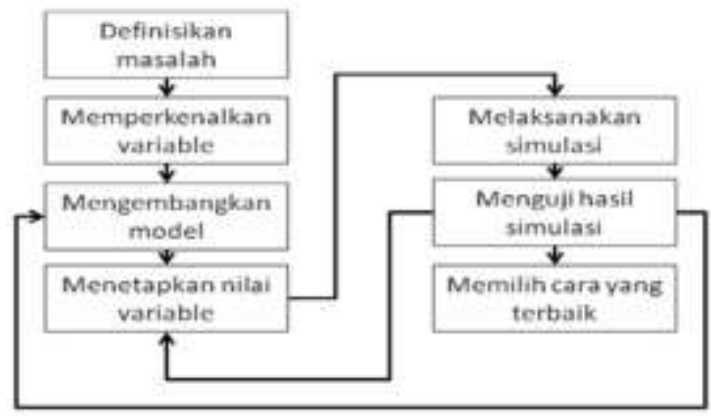

Gambar 1 Metode Penelitian

1. Definisikan Masalah

Mendefinisikan masalah dengan cara menganalisa sistem persediaan yang sedang berjalan dan pengumpulan data yang di perluakan dalam penelitian ini sebagai berikut:

a. Ketidakpastian dalam permintaan, sehingga besarnya permintaan merupakan variabel bebas yang di acak (random).

b. Ketidakpastian lead time, sehingga besarnya lead time merupakan variabel bebas yang di acak (random).

c. Pemesanan dilakukan ketika posisi persediaan (stock) berada dibawah atau sama dengan nilai reorder point yang telah ditetapkan.

d. Perusahaan melakukan pemesanan kembali dengan jumlah yang sama ketika tingkat persediaan barangnya mencapai jumlah tertentu (perpetual inventory system) .

e. Persedian dalam model ini hanya persedian satu item barang (pupuk).

2. Memperkenalkan variabel
Menetapkan variabel input yang akan digunakan dari hasil analisa sistem persediaan yang sedang berjalan, sebagai berikut :

1. Controllable input : merupakan variabel input yang sifatnya dapat dikendalikan oleh sistem, yaitu :
a. Persediaan awal
b. Reorder point
c. Jumlah pesanan
d. Jumlah pengulangan (simulasi)

2. Probabilistic input : merupakan variabel input yang sifatnya dihasilkan secara acak (random), yaitu:

a. Lead time dan frekuensinya

Setelah di input lead time dan frekuensinya maka outputnya akan menghasilkan probabilitas lead time, seperti lead time, frekuensi, probabilitas, kumulatif, interval awal dan interval akhir.

b. Penjualan dan frekuensinya

Setelah di input penjualan dan frekuensinya maka outputnya akan menghasilkan probabilitas penjualan, seperti penjualan, frekuensi, probabilitas, kumulatif, interval awal dan interval akhir.

3. Mengembangkan Model

Penelitian simulasi inventori ini menggunakan pendekatan simulasi untuk model persediaan stokastik. Model persediaan stokastik merupakan model persediaan yang melibatkan tingkat penjualan (demand) dan periode kedatangan pesanan (lead time) tidak dapat diketahui secara pasti sebelumnya, sehingga harus menggunakan probabilitas lead time dan probabilitas penjualan. Pengumpulan data lead time dan data permintaan (demand) pelanggan tersebut diperoleh berdasarkan tanya-jawab dan pengamatan secara langsung (observasi) dari data kejadian sebelumnya/dari data masa lalu (data historis).

4. Menetapkan Nilai Variabel 
Penelitian ini memiliki nilai variabel input yang diperoleh dari hasil pengamatan data historis pada PT. Bingei Medan. Untuk variabel controllable input (persediaan awal, reorder point, jumlah pesanan dan jumlah pengulangan) nilai sudah ditentukan dan untuk variabel probabilistic input, terdiri dari lead time dan penjualan.

5. Melaksanakan Simulasi

Membangun simulas untuk model persedian stokastik dengan menggunakan bahasa pemograman Microsoft Visual Basic yang ditentukan berdasarkan controllable input dan probabilistic input serta output dari hasil simulasi merupakan karakteristik sistem persediaan.

6. Menguji Hasil Simulasi

Menguji hasil simulasi dengan rangkaian percobaan/simulasi untuk menganalisis bagaimana karakteristik sebuah sistem persediaan yang ditentukan berdasarkan controllable input dan probabilistic input.

7. Memilih cara yang terbaik

Hasil akhir simulasi adalah karakteristik sistem inventori yang menghasilkan kesimpulan simulasi, sebagai berikut :

a. Tingkat ketersediaan (stock) awal dan ketersediaan (stock) akhir.

b. Rata-rata stock awal, stock akhir dan stock out.

c. Jumlah pesan, jumlah stock out dan total waktu pemesanan.

Nilai karakteristik sistem inventori tersebut diperoleh dengan melakukan rangkaian percobaan simulasi untuk dapat memilih cara yang terbaik.

\section{HASIL DAN PEMBAHASAN}

Hasil penelitian ini berupa program simulasi untuk model persediaan stokastik yang dibangun dengan menggunakan bahasa pemograman Microsoft Visual Basic 6.0. Program simulasi ini terdiri dari dua jenis input, yaitu :

1. Controllable input : merupakan variabel input yang sifatnya dapat dikendalikan oleh sistem, yaitu :
a. Persediaan awal
b. Reorder point
c. Jumlah pesanan
d. Jumlah pengulangan (simulasi)

2. Probabilistic input merupakan variabel input yang sifatnya dihasilkan secara acak (random), yaitu:

a. Lead time dan frekuensinya

Setelah di input lead time dan frekuensinya maka outputnya akan menghasilkan probabilitas lead time, seperti lead time, frekuensi, probabilitas, kumulatif, interval awal dan interval akhir.

b. Penjualan dan frekuensinya

Setelah di input penjualan dan frekuensinya maka outputnya akan menghasilkan probabilitas penjualan, seperti penjualan, frekuensi, probabilitas, kumulatif, interval awal dan interval akhir.

Simulasi untuk model persediaan stokastik dilakukan dengan rangkaian percobaan agar mendapatkan nilai karakteristik sistem persediaan yang baik pula. Simulasi dilakukan dengan percobaan controllable input sebagai berikut :

a. Persediaan awal $=600$ Karung

b. Reorder point $=300$ Karung

c. Jumlah pesanan $=600$ Karung

d. Jumlah pengulangan $=30$ Hari dan probabilistic input terdiri dari :

a. Lead Time merupakan periode kedatangan pesanan atau waktu yang dibutuhkan untuk kedatangan pesanan. Data Lead Time diperoleh dari hasil pengamatan kejadian sebelumnya selama 60 hari seperti pada tabel 1

Tabel 1 Lead Time

\begin{tabular}{|c|c|}
\hline Lead Time & Frekuensi \\
\hline 1 & 4 \\
\hline 2 & 8 \\
\hline 3 & 2 \\
\hline
\end{tabular}

b. Penjualan merupakan permintaan kebutuhan pelanggan. Data penjualan diperoleh dari hasil pengamatan 
kejadian sebelumnya selama 60 hari seperti pada tabel 2

Tabel 2 Penjualan
\begin{tabular}{|c|c|}
\hline Penjualan & Frekuensi \\
\hline 120 & 11 \\
\hline 121 & 6 \\
\hline 122 & 9 \\
\hline 123 & 5 \\
\hline 124 & 8 \\
\hline 125 & 10 \\
\hline 126 & 7 \\
\hline 127 & 4 \\
\hline
\end{tabular}

Pembahasan penelitian simulasi untuk model persediaan stokastik ini dimulai dari proses simulasi sebelum dijalankan (gambar 3.1), maka diperlukan langkah-langkah sebagai berikut:

1. Input Persediaan Awal dengan syarat tidak boleh negatif. Persediaan awal merupakan Jumlah barang yang ready di awal pembukaan transaksi penjualan pupuk. berdasarkan percobaain ini jumlah persediaan awal adalah 600 karung.

2. Input Reorder Point dengan syarat tidak boleh kurang dari atau sama dengan 0 , bagian ini menentukan berapa stok minimal yang harus tersedia di gudang dan jika persediaan akhir kurang atau sama dengan Reorder Point, maka perlu melakukan pemesanan (Order). Berdasarkan percobaan ini Reorder Point adalah 300 karung.

3. Input Jumlah Pesanan dengan syarat tidak boleh kurang dari atau sama dengan 0 , bagian ini menentukan berapa jumlah barang yang harus dipesan ketika stok awal sudah sama atau kurang dari Reorder Point. Berdasarkan percobaan ini Jumlah Pesanan adalah 600 karung.

4. Input Jumlah Pengulangan dengan syarat tidak boleh negatif, bagian ini menentukan untuk berapa hari proses simulasi ini dilakukan. Berdasarkan percobaan ini disimulasikan selama 30 hari.
5. Input Lead Time terdapat dua kolom yang digunakan yaitu input Lead Time dan frekuensinya berdasarkan tabel 1 .

6. Input Penjualan terdapat dua kolom yang digunakan yaitu input penjualan dan frekuensinya berdasarkan tabel 2 .

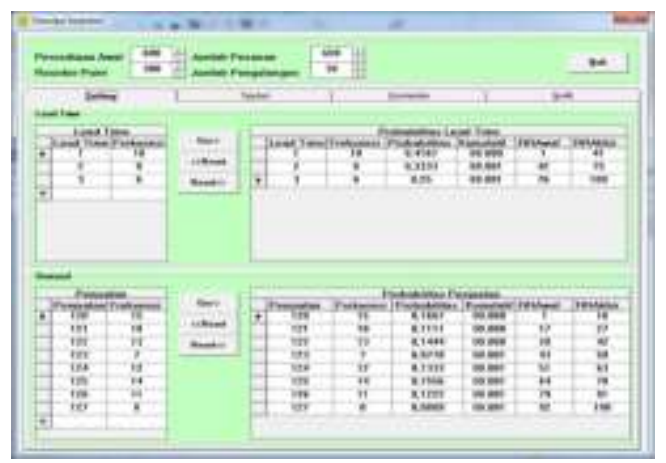

Gambar 2 Input

Setelah melakukan langkah 1 sampai 6, maka langkah selanjutnya yaitu menjalankan proses simulasi untuk model persediaan stokastik yang terdapat pada menu tabulasi simulasi. Simulasi dijalankan dengan menekan tombol run pada menu tabulasi simulasi. Simulasi dijalankan sesuai dengan controllable input dan probabilistic input.

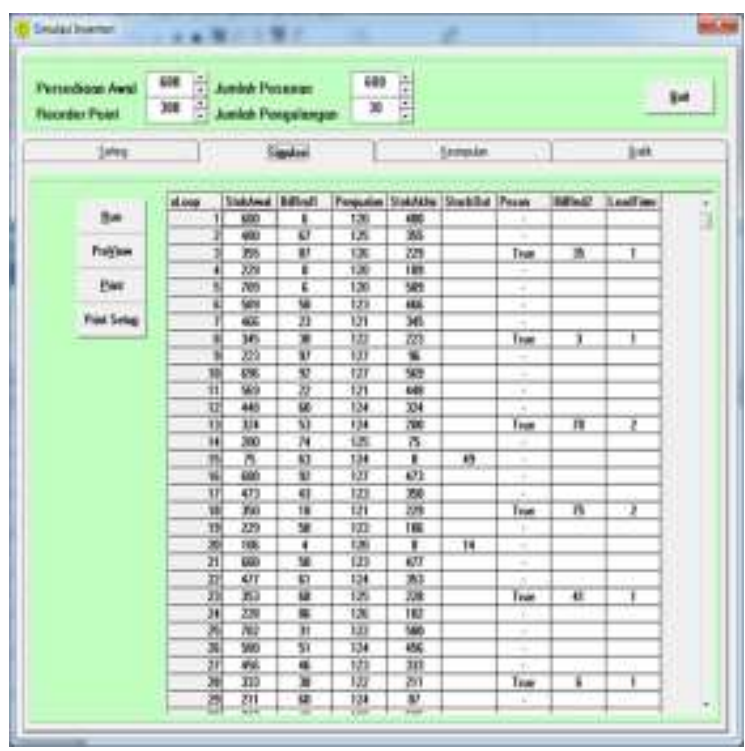

Gambar 3 Hasil Simulasi

Maka hasil simulasi selama 30 hari dapat dilihat pada gambar 3, sebagai berikut : 
1. Stok awal merupakan jumlah barang yang ready di awal pembukaan transaksi penjualan.

2. Xloop merupakan jumlah pengulangan dari simulasi yang dilakukan dengan satuan hari, dalam percobaan ini dilakukan selama 30 hari, maka xloop akan akan menampilkan hasil simulasi sampai dengan 30 kali seperti gambar 2.

3. BilRnd1 merupakan bilangan acak penjualan yang dibangkitkan berdasarkan probabilitas penjualan.

4. Penjualan merupakan nilai yang diperoleh dari interval awal dan atas berdasarkan bilangan acak penjualan (BilRnd1) yang dibangkitan.

5. Stok akhir merupakan hasil pengurangan antara stok awal dengan penjualan.

6. Stock Out merupakan permintaan pelanggan yang tidak terpenuhi. jika nilai penjualan melebihi stok awal, maka nilai stock out berdasarkan pengurangan antara penjualan dengan stok awal.

7. Pesan merupakan perintah untuk melakukan pemesanan barang untuk menambah stok awal sebanyak jumlah pesanan. Jumlah barang yang harus dipesan ketika jumlah stok awal sudah sama atau kurang dari Reorder Point.

8. BilRnd2 merupakan bilangan acak lead time yang dibangkitkan berdasarkan Probabilitas lead time.

9. Lead time merupakan nilai yang diperoleh dari interval awal dan atas berdasarkan bilangan acak lead time (BilRnd2) yang dibangkitan.

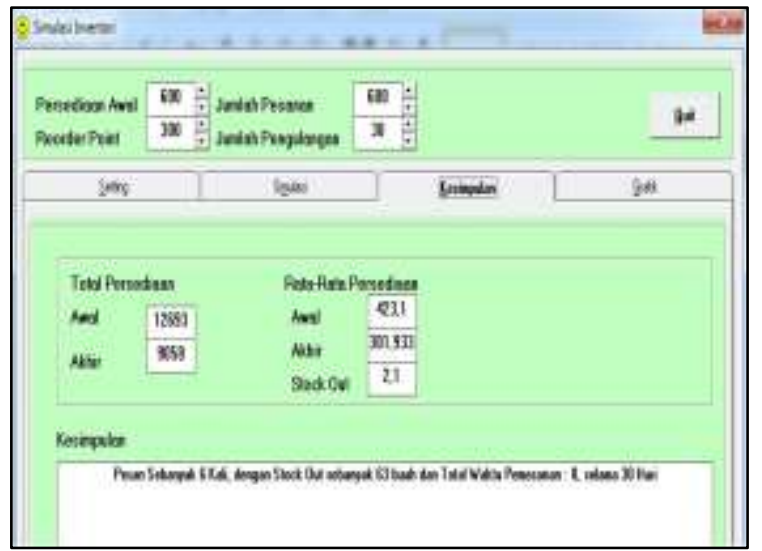

Gambar 4 Kesimpulan Simulasi

Kesimpulan dari hasil simulasi dapat dilihat pada menu tabulasi kesimpulan. Berdasarkan simulasi untuk model persediaan stokastik dengan percobaan simulasi selama 30 hari, maka karakteristik sistem persediaan (gambar 3.3), sebagai berikut :

1. Total Persediaan :

a. Awal $=12693$ Karung

Total persediaan awal ini diperoleh berdasarkan jumlah stok awal selama pengulangan simulasi 30 hari.

b. Akhir $=9058$ Karung.

Total persediaan akhir ini diperoleh berdasarkan jumlah stok akhir selama pengulangan simulasi 30 hari.

2. Rata-rata persediaan :

a. Awal $=423,1$ Karung

Rata-rata persediaan awal ini diperoleh berdasarkan total persediaan awal dibagi jumlah pengulangan simulasi.

b. $\quad$ Akhir $=301,9$ Karung

Rata-rata persediaan akhir ini diperoleh berdasarkan total persediaan akhir dibagi jumlah pengulangan simulasi.

c. Stock Out $=2,1$ Karung

Rata-rata stock out ini diperoleh berdasarkan total stock out dibagi jumlah pengulangan simulasi.

Dari hasil simulasi untuk model persediaan stokastik dengan percobaan simulasi selama 30 hari, maka kesimpulan simulasi pada gambar 3.3 sebagai berikut :

a. Pesan sebanyak 6 Kali 
Perintah pesan barang ke pemasok untuk menambah persediaan awal (stok awal) dilakukan sebanyak 14 kali selama 30 hari simulasi.

b. Stock out sebanyak 63 Karung Permintaan pelanggan yang tidak terpenuhi sebanyak 63 karung pupuk selama 30 hari simulasi.

c. Total waktu pemesanan adalah 8 hari Total waktu pemesanan merupakan waktu yang dibutuhkan untuk kedatangan pesanan diperoleh berdasarkan total lead time yang ada selama 30 hari simulasi yaitu 8 hari.

\section{KESIMPULAN}

Berdasarkan uraian diatas, maka kesimpulan penelitian ini sebagai berikut:

1. Simulasi Inventori Untuk Model Stokastik Pada PT. Bingei Medan ditentukan berdasarkan controllable input (persediaan awal, reorder point, jumlah pesanan dan jumlah pengulangan) dan probabilistic input (lead time dan frekuensinya serta penjualan dan frekuensinya).

2. Simulasi Inventori Untuk Model Persediaan Stokastik dilakukan dengan nilai controllable input dan nilai probabilistic input (tabel 3.1 dan 3.2), sebagai berikut:
a. Persediaan awal $=500$ Karung
b. Reorder point $=300$ Karung
c. Jumlah pesanan $=500$ Karung
d. Jumlah pengulangan $=60$ Hari

Kesimpulan hasil Simulasi Inventori Untuk Model Persediaan Stokastik dengan percobaan simulasi selama 30 hari, maka karakteristik sistem persediaan sebagai berikut :

A. Total persediaan :

a. Awal $=12693$ Karung.

b. Akhir $=9058$ Karung.

B. Rata-rata persediaan :
a. Awal $=423,1$ Karung.
b. Akhir $=301,9$ Karung.
c. Stock Out $=2,1$ Karung.

Dari hasil Simulasi Inventori Untuk Model Persediaan Stokastik dengan percobaan simulasi selama 30 hari, maka kesimpulan simulasi sebagai berikut:
a. Pesan sebanyak 6 Kali
b. Stock out sebanyak 63 Karung
c. Total waktu pemesanan adalah 8 hari

\section{DAFTAR PUSTAKA}

[1] Arief, $\mathrm{S}$ dan Aji, T. (2013). Pengendalian Persediaan Menggunakan Simulasi Berbasis Spreadsheet (Studi Kasus: Jaringan Toko Sepatu Olahraga), Kaunia, Vol. IX, No. 1, April 2013: 53-62.

[2] Egar, A. D dan Setio, S. W (2016). Analisis Sistem Persediaan Sparepart Motor Di Bengkel Aneka Sakti. Seminar Nasional IENACO - 2016: 140-147.

[3] Icun, Holy.Y dan Getty, Martinus S, Business Concepts Implementation Series in Inventory Management, Penerbit Elex Media Komputindo, Jakarta, 2005.

[4] Nur, Senator. B, Sistem Inventori, Penerbit ITB, Bandung, 2006.

[5] Sridadi, B., 2009, Pemodelan Dan Simulasi Sistem, Penerbit Informatika Bandung.

[6] Sugiarto,B. (2007). Aplikasi Simulasi Untuk Peramalan Permintaan Dan Pengelolaan Persediaan Yang Bersifat Probabilistik, INASEA, Vol. 8112 No.2, Oktober 2007: 112-120. 